\title{
Kadar Seng Plasma Pasien Tuberkulosis Anak: Studi Pendahuluan
}

\author{
Bertha Soegiarto, I Boediman, Zakiudin Munasir \\ Departemen Ilmu Kesehatan Anak FKUI RS Dr. Cipto Mangunkusumo, Jakarta
}

\begin{abstract}
Latar belakang. Tuberkulosis (TB) menjadi masalah kesehatan di Indonesia, oleh karena dengan meningkatnya pasien TB dewasa, terjadi juga peningkatan anak yang terinfeksi dan sakit TB. defisiensi mikronutrien tertentu termasuk seng sangat mempengaruhi sistem imunitas pejamu, padahal imunitas selular sangat berpengaruh terhadap perjalanan penyakit TB. Penelitian tentang status mikronutrien pada pasien TB anak masih sangat terbatas.

Tujuan. Menentukan kadar seng plasma pasien TB anak, kadar seng plasma pasien TB anak pada berbagai tahap pengobatan OAT dan kadar seng plasma pasien TB anak baru dengan indurasi uji Mantoux yang berbeda.

Metode. Penelitian potong lintang dilaksanakan di unit rawat jalan dan rawat inap Departemen Ilmu Kesehatan Anak FKUI-RSCM dalam kurun waktu April - Mei 2008. Dari 84 pasien TB anak, 30 di antaranya diikutsertakan dalam penelitian. Tiga mililiter darah vena diambil dari pasien dan dikirim ke Laboratorium SEAMEO-TROPMED Universitas Indonesia untuk dilakukan analisis kadar seng plasma.

Hasil. Dua puluh lima dari tiga puluh pasien TB anak memiliki kadar seng plasma di bawah nilai normal, dengan rerata $(9,0 \pm 1,8) \mu \mathrm{mol} / \mathrm{L}$. Sebelum terapi OAT dimulai, kadar seng plasma lebih rendah daripada setelah mendapatkan terapi OAT. Pasien dengan uji Mantoux negatif memiliki kadar seng plasma lebih rendah daripada pasien dengan uji Mantoux positif.

Kesimpulan. Pasien TB anak memiliki kadar seng plasma di bawah nilai normal. Kadar seng plasma pasien TB baru lebih rendah daripada pasien TB yang sudah mendapatkan terapi OAT. Pasien dengan uji Mantoux negatif memiliki kadar seng plasma lebih rendah daripada pasien dengan uji Mantoux positif.
\end{abstract}

(Sari Pediatri 2008;10(4):236-41).

Kata kunci: tuberkulosis anak, kadar seng plasma, uji Mantoux

Alamat Korespondensi:
Dr. Bertha Soegiarto, SpA. Taman Cengkareng Indah AC/12, Jakarta
11720 5409728/081510391363. Email : bertha_soegiarto@hotmail.com uberkulosis (TB) masih merupakan masalah kesehatan di dunia dan merupakan salah satu penyebab kematian terbanyak terutama di negara sedang berkembang. Indonesia menempati urutan ketiga dalam jumlah insidens TB di dunia setelah India dan Cina. ${ }^{1-3}$ Respons 
sistem imun selular merupakan faktor penting dalam perjalanan penyakit TB, karena menentukan apakah seseorang yang terpajan kuman TB mampu mengatasi infeksi atau berkembang menjadi penyakit. Respons imun juga berperan pada kelainan patologik penyakit TB dan hasil akhir perjalanan penyakit. ${ }^{4}$ Mekanisme defisiensi nutrien seng merupakan salah satu penyebab gangguan sistem imunitas terutama imunitas selular. ${ }^{5}$

Gejala klinis TB anak seringkali tidak spesifik, sehingga untuk mendiagnosis penyakit TB anak terdapat beberapa kriteria diagnosis yang harus dipenuhi. Uji tuberkulin merupakan salah satu cara yang cukup sederhana dan efektif untuk menunjang diagnosis TB. Namun beberapa keadaan immunocompromised, misalnya pada gizi buruk, dapat menyebabkan hasil negatif palsu (anergi). Sistem imunitas selular yang terganggu akibat defisiensi seng pada pasien TB juga dapat menyebabkan hasil negatif palsu pada uji tuberkulin yang turut berperan dalam keterlambatan diagnosis TB anak.

Malnutrisi sering terjadi pada pasien TB, namun baru sedikit yang diketahui mengenai status mikronutrien seperti seng (zinc/Zn), besi dan vitamin A pada pasien TB. ${ }^{6}$ Penelitian mengenai kadar seng plasma pada pasien TB dewasa sudah banyak dilakukan, namun penelitian serupa pada pasien TB anak masih sedikit dilakukan. Penelitian bertujuan mencari rerata kadar seng plasma pasien TB anak yang baru didiagnosis dengan besar indurasi uji tuberkulin yang berbeda dan rerata pada pasien TB anak dengan lama pengobatan OAT yang berbeda.

\section{Metode}

Penelitian telah lolos kaji etik dari Komisi Etik FKUI-RSCM. Populasi penelitian mencakup pasien TB anak yang berobat di ruang rawat jalan dan rawat inap Departemen Ilmu Kesehatan Anak FKUI-RSCM yang berusia $\leq 12$ tahun untuk pasien laki-laki dan $\leq 10$ tahun untuk perempuan. Pasien dalam keadaan immunocompromised seperti gizi buruk, HIV, keganasan, dalam terapi steroid jangka panjang dan kemoterapi serta menderita infeksi akut saat penelitian tidak diikutsertakan dalam penelitian. Setelah orangtua mendapat penjelasan dan menandatangani informed consent, dilakukan anamnesis, pemeriksaan antropometri, dan pemeriksaan fisik. Tiga milimeter darah vena diambil dan dikirim dalam wadah pendingin ke laboratorium SEAMEO-TROPMED Universitas Indonesia untuk diperiksa kadar seng dalam plasma. Semua alat dan tabung yang digunakan untuk pemeriksaan telah dicuci dengan asam nitrat sebelumnya untuk menghindari kesalahan pemeriksaan. Kadar seng plasma diperiksa dengan alat atomic absorption spectrophotometer (GBC model 933 AA, Victoria, Australia) pada gelombang $\lambda$ 213,9 nm dengan kontrol menggunakan Biorad: lypocheck assayed chemistry control (human).

\section{Hasil}

Selama kurun waktu penelitian didapatkan 84 pasien $\mathrm{TB}, 30 \mathrm{di}$ antaranya memenuhi kriteria penelitian. Tertera pada Tabel 1, pasien TB pada penelitian ini berusia antara 11 bulan sampai 12 tahun dengan rerata usia $(59,4 \pm 40,2)$ bulan. Jenis kelamin terdiri dari 18 laki-laki dan 12 perempuan dengan perbandingan antara laki-laki dan perempuan 1,5:1. Sebagian besar subjek penelitian memiliki status gizi baik, 20 orang dari 30 subjek. Kontak pasien dengan pasien TB dewasa ditemukan pada 15 subjek.

Tabel 2 menggambarkan manifestasi klinis subjek penelitian saat sebelum pengobatan TB dimulai. Dari 30 orang subjek, 25 di antaranya menunjukkan hasil uji

Tabel 1. Karakteristik subjek penelitian

\begin{tabular}{lc}
\hline \multicolumn{1}{c}{ Karakteristik } & Jumlah $(\mathrm{n}=30)$ \\
\hline Usia (tahun) & \\
$\quad<1$ & 1 \\
$1-3$ & 11 \\
$>3-6$ & 11 \\
$\quad>6-12$ & \\
Jenis kelamin & 18 \\
$\quad$ Laki-laki & 12 \\
$\quad$ Perempuan & \\
Status nutrisi & 20 \\
$\quad$ Gizi baik & 10 \\
Gizi kurang & \\
Kontak TB & 15 \\
Ada & 15 \\
Tidak & \\
\hline
\end{tabular}


Tabel 2. Gambaran klinis subjek penelitian

\begin{tabular}{lc}
\hline \multicolumn{1}{c}{ Manifestasi klinis } & $\begin{array}{c}\text { Jumlah } \\
(\mathrm{n}=30)\end{array}$ \\
\hline Uji Mantoux $(+)$ & 25 \\
Gejala klinis* & \\
Demam $\geq 2$ minggu & 12 \\
Batuk >3 minggu & 13 \\
Berat badan turun tanpa sebab jelas & 12 \\
Napsu makan berkurang, gagal tumbuh & 25 \\
Gambaran radiologis dada & \\
Infiltrat & 8 \\
Pembesaran kelenjar getah bening hilus & 8 \\
Infiltrat \& pembesaran kelenjar getah & 11 \\
bening hilus & 2 \\
Milier & 1 \\
Efusi pleura & \\
Diagnosis tuberkulosis* & 16 \\
TB paru & 3 \\
TB meningitis & 2 \\
TB milier & \\
TB poliserositis (efusi pleura \& asites) & 1 \\
Limfadenopati TB & 3 \\
Skrofuloderma & \\
TB tulang (spondilitis \& koksitis) & 4 \\
\hline * orang subjek dapat menderita 1 atau lebih gejala klinis/diagnosis \\
\end{tabular}

Gambar 1. Proporsi hipozinsemia pada 30 pasien TB anak

Mantoux positif dengan gejala klinis terbanyak adalah kurang nafsu makan disertai dengan gagal tumbuh, yaitu 25 subjek. Gambaran radiologis dada yang diambil pada saat diagnosis TB ditegakkan paling banyak menunjukkan gambaran infiltrat disertai pembesaran kelenjar getah bening hilus, dapat ditemui pada 11 subjek. Diagnosis TB terbanyak adalah TB paru 16 subjek, 3 subjek yang menderita TB berat yaitu TB
Tabel 3. Rerata kadar seng plasma menurut lama pengobatan TB dan uji Mantoux

\begin{tabular}{cc}
\hline Parameter & $\begin{array}{c}\text { Rerata kadar seng plasma } \\
\pm S D(\mu \mathrm{mol} / \mathrm{L})\end{array}$ \\
\hline Status pengobatan TB $(\mathrm{n}=30)$ & \\
Sebelum pengobatan & $8,5 \pm 1,8$ \\
Pengobatan $\leq 2$ bulan & $9,6 \pm 1,2$ \\
Pengobatan $>2$ bulan & $9,1 \pm 2,1$ \\
Indurasi uji Mantoux $(\mathrm{n}=9)$ & \\
negatif & $7,2 \pm 3,5$ \\
positif & $8,8 \pm 1,5$ \\
\hline
\end{tabular}

meningitis dan TB milier (didapatkan pada 2 orang subjek yang juga menderita TB meningitis)

Berdasarkan pemeriksaan kadar seng plasma, rerata kadar seng plasma adalah $(9,0 \pm 1,8) \mu \mathrm{mol} / \mathrm{L}$ dengan kisaran antara $(4,9-11,8) \mu \mathrm{mol} / \mathrm{L}$. Gambar 1 menunjukkan proporsi hipozincemia pada 25 dari 30 subjek (kadar seng plasma di bawah 10,7 $\mu \mathrm{mol} / \mathrm{L}$ ), hanya 5 subjek menunjukkan kadar seng plasma normal.

Tabel 3 menggambarkan kadar seng plasma TB anak dengan lama pengobatan dan indurasi uji Mantoux yang berbeda. Pada saat pengobatan TB belum dimulai, rerata kadar seng plasma subjek $(8,5 \pm 1,8) \mu \mathrm{mol} / \mathrm{L}$ dengan kisaran antara $(5-10,1)$ $\mu \mathrm{mol} / \mathrm{L}$. Sedangkan setelah pengobatan dimulai, rerata kadar seng plasma menjadi $(9,6 \pm 1,2) \mu \mathrm{mol} / \mathrm{L}$ (kisaran $7,7-11 \mu \mathrm{mol} / \mathrm{L})$ pada terapi $\leq 2$ bulan dan $(9,1 \pm 2,1)$ $\mu \mathrm{mol} / \mathrm{L}$ (kisaran 4,9-11,8 $\mu \mathrm{mol} / \mathrm{L}$ ) pada terapi $>2$ bulan.

Kadar seng plasma dikaitkan dengan besar indurasi uji Mantoux digambarkan pada subjek yang belum mendapatkan terapi TB (9 pasien). Pasien dengan uji Mantoux negatif memiliki rerata kadar seng plasma $(7,2 \pm 3,5) \mu \mathrm{mol} / \mathrm{L}$ dengan kisaran 5-9,3 $\mu \mathrm{mol} / \mathrm{L}$, sedangkan pasien dengan hasil uji positif memiliki rerata $(8,8 \pm 1,5) \mu \mathrm{mol} / \mathrm{L}$ dengan kisaran $(5,7-11)$ $\mu \mathrm{mol} / \mathrm{L}$.

\section{Pembahasan}

Seng merupakan mediator poten terhadap daya tahan tubuh terhadap infeksi, karena mempengaruhi imunitas nonspesifik dan spesifik. Pengaruh seng terhadap sistem imun nonspesifik meliputi barrier tubuh seperti epitel kulit, mukosa gastrointestinal dan 
saluran napas. Defisiensi seng akan mempengaruhi mediator imunitas nonspesifik seperti fungsi leukosit polimorfonuklear (PMN), makrofag, sel NK, dan aktivitas komplemen. Seng juga merupakan salah satu faktor penting dalam sistem imun spesifik yaitu pertumbuhan dan fungsi limfosit, aktivasi limfosit, produksi sitokin (terutama sitokin Th1), dan lain sebagainya. ${ }^{7,8}$

Kadar seng normal dalam plasma $(10,7-18,3)$ $\mu \mathrm{mol} / \mathrm{L}$ sering dipakai sebagai indikator kadar seng dalam tubuh seseorang. ${ }^{9,10}$ Kadar seng plasma merupakan indikator penting dari tempat penyimpanan seng (exchangeable pool). Penurunan seng plasma mencerminkan penurunan seng dari tulang dan hati, merupakan faktor risiko terjadinya defisiensi seng secara klinis. Penurunan kadar seng dalam plasma (hipozinsemia) sering dikaitkan dengan berbagai masalah seperti gangguan epitelisasi kulit, penurunan fungsi imun terutama imunitas selular, gangguan pertumbuhan dan sebagainya. Gangguan imunitas selular dikatakan sudah dapat terjadi pada defisiensi seng marginal, walaupun gejala-gejala defisiensi seng lainnya belum muncul. ${ }^{9,11}$ Seng merupakan salah satu faktor penting dalam fungsi sistem imun selular yang merupakan respons imun utama pada infeksi TB. Rendahnya kadar seng dalam darah atau hipozinsemia ditemukan pada pasien TB seperti yang telah dikemukakan pada beberapa studi. ${ }^{6,12-14}$

Penelitian kami merupakan suatu penelitian potong lintang dengan memeriksa kadar seng plasma pada pasien TB anak. Hasil penelitian menggambarkan proporsi hipozinsemia dan rerata kadar seng plasma pasien TB anak. Selain itu, subjek pada penelitian tidak mendapatkan analisis diet dan intervensi diet sehingga mungkin terdapat variasi asupan makanan yang mengandung seng atau yang menghambat penyerapan seng dan dapat mempengaruhi kadar seng dalam plasma.

Pasien TB pada penelitian 30 orang, berusia 11 bulan hingga 12 tahun dengan rerata usia $(59,4 \pm 40,2)$ bulan. Dari 30 orang subjek, 19 orang berusia di bawah 6 tahun, sesuai dengan Survei Prevalensi TB Nasional tahun 2004 dan penelitian oleh Supriyatno B dkk. bahwa sebagian besar pasien TB anak berusia $<5$ tahun. Pada Survei Prevalensi TB Nasional tahun 2004 terlihat peningkatan jumlah anak $<5$ tahun yang didiagnosis menderita TB sejak tahun 2000 dari 4,5\% menjadi $39,7 \% .{ }^{15}$ Supriyatno B dkk ${ }^{16}$ menunjukkan bahwa $55 \%$ dari 171 pasien yang menderita TB dengan biakan positif berusia $\leq 5$ tahun. Hal ini dapat dimengerti mengingat usia balita sangat rentan terhadap infeksi, termasuk TB.

Pasien TB dengan status gizi buruk tidak diikutsertakan dalam penelitian ini, 10 dari 30 subjek berstatus gizi kurang. Terdapat hubungan yang sangat erat antara status gizi, fungsi imun, dan infeksi. Malnutrisi memperburuk imunitas selular dan respon terhadap infeksi, sebaliknya infeksi menyebabkan penurunan berat badan, malnutrisi, dan disfungsi sistem imun. Namun pada pasien TB sangat sulit untuk menentukan dengan akurat status gizi mereka sebelum terinfeksi $\mathrm{TB}$, sehingga sulit menentukan apakah malnutrisi menyebabkan TB atau sebaliknya. ${ }^{17}$ Seperti yang telah dijelaskan sebelumnya bahwa kuman TB dapat menginfeksi semua orang bila sistem imun terutama sistem imun selular mereka tidak optimal tanpa memandang status nutrisi pejamu. Seseorang dengan status gizi baik masih dapat terinfeksi kuman TB apabila mengalami gangguan fungsi imunitas selular salah satunya akibat status mikronutrien yang kurang baik. Defisiensi seng marginal dapat menyebabkan gangguan imunitas selular sebelum menimbulkan tanda-tanda defisiensi seng, hal tersebut memperbesar risiko individu terhadap infeksi termasuk TB.

Adanya kontak dengan orang dewasa yang menunjukkan gejala atau didiagnosis TB ditemukan pada 15 subjek dari 30 subjek yang diteliti. Sejalan dengan peningkatan angka prevalensi TB di Indonesia dengan peningkatan pasien TB dengan pemeriksaan BTA positif menjadi 170,5 per 100.000 penduduk pada survei prevalensi TB Nasional tahun 2004. ${ }^{15}$ Sebagian besar subjek pada penelitian ini 25 orang menunjukkan hasil uji Mantoux positif, yang ditunjukkan dengan besar indurasi $\geq 10 \mathrm{~mm}$. Tiga orang dari 5 subjek dengan hasil uji Mantoux negatif menderita TB berat yaitu TB meningitis dan TB milier.

Manifestasi klinis TB anak sangat beragam dan seringkali tidak spesifik, Supriyatno B dkk ${ }^{16}$ mengemukakan bahwa demam merupakan gejala klinis terbanyak dijumpai pada pasien TB anak $(81,3 \%)$ diikuti dengan batuk $(79,5 \%)$, anoreksia, keringat malam $(63,7 \%)$, dan penurunan berat badan $(56,7 \%) .{ }^{16}$ Rahajoe NN dkk ${ }^{3}$ juga menyatakan bahwa demam merupakan gejala klinis yang paling sering dikeluhkan orangtua, berkisar antara 40\%-80\%. Kami mendapatkan, manifestasi klinis yang paling banyak dikeluhkan orangtua sebelum dimulai pengobatan adalah anoreksia dengan kesulitan peningkatan berat 
badan (25/30 subjek), diikuti dengan batuk (13/30 subjek), demam, dan penurunan berat badan (masingmasing 12/30 subjek). Diagnosis TB paru merupakan diagnosis TB terbanyak (16/30 subjek), TB meningitis dan milier yang termasuk dalam kategori TB berat didapatkan pada 3 orang subjek. Rahajoe NN dkk ${ }^{3}$ menyatakan bahwa jenis TB tersering pada anak adalah TB paru, sedangkan TB miler atau TB berat lebih jarang ditemukan yang berkisar antara 3\%-7\% dari seluruh kasus TB.

Rerata kadar seng plasma di bawah nilai normal $(10,7-18,3) \mu \mathrm{mol} / \mathrm{L}$ yaitu $(9,0 \pm 1,8) \mu \mathrm{mol} / \mathrm{L}$, mencapai 25/30 subjek. Subjek dengan TB berat (TB meningitis dan milier) menunjukkan rerata kadar seng plasma yang lebih rendah, $(8,2 \pm 2,8) \mu \mathrm{mol} / \mathrm{L}$. Hasil tersebut masih harus dikonfirmasikan lebih lanjut karena dalam penelitian kami subjek yang menderita TB berat sangat sedikit. Penelitian Ray $\mathrm{dkk}^{12}$ menunjukkan kadar seng plasma rendah pada pasien TB paru anak, $(10,5 \pm 0,3)$ $\mu \mathrm{mol} / \mathrm{L}$ dan bahkan hasil yang lebih rendah terlihat pada pasien TB berat $(9,8 \pm 3,1) \mu \mathrm{mol} / \mathrm{L}$ pada TB meningitis dan $(9,0 \pm 0,4) \mu \mathrm{mol} / \mathrm{L}$ pada TB diseminata. Penelitian terhadap pasien TB dewasa yang dilakukan di India dan Indonesia juga menunjukkan kadar seng plasma pasien TB lebih rendah jika dibandingkan dengan kelompok kontrol yang tidak menderita TB. ${ }^{14}$

Seng merupakan mikronutrien yang sangat penting, merupakan modulator sistem imun terutama sistem imun selular, dan sangat berperan dalam respons tubuh terhadap kuman TB. Hipozinsemia pada pasien TB anak bersifat multifaktorial. Pertama, perubahan distribusi seng dalam jaringan tubuh sebagai reaksi terhadap infeksi kronis. Pelepasan mediator endogen oleh leukosit menyebabkan seng dan asam amino masuk ke hati yang digunakan untuk sintesis reaktan fase akut, sehingga kadar seng dalam plasma menjadi menurun. Kedua, seng juga digunakan oleh kuman TB untuk pertumbuhan dan multiplikasi terbukti dengan ditemukan akumulasi seng pada lokasi lesi TB. ${ }^{6,14}$ Pendapat tersebut menunjang pendapat yang menyatakan bahwa penurunan kadar seng plasma lebih rendah pada TB berat karena jumlah kuman di dalam tubuh lebih banyak. Ketiga, hipozinsemia pada pasien TB mungkin juga disebabkan karena asupan makanan yang kurang baik sehingga menyebabkan penurunan status gizi.

Rerata kadar seng plasma subjek dengan gizi kurang lebih rendah dibandingkan dengan subjek dengan status gizi baik $(8,2 \pm 1,6 \mu \mathrm{mol} / \mathrm{L}$ dan $9,5 \pm 1,9$ $\mu \mathrm{mol} / \mathrm{L})$. Pendapat yang sama juga dinyatakan oleh Karyadi dan Ray dkk ${ }^{12,14}$ yang membandingkan pasien TB dengan kelompok kontrol sehat dan malnutrisi tanpa TB. Penelitian mereka menunjukkan bahwa rerata kadar seng plasma pasien TB lebih rendah dibandingkan dengan kelompok kontrol tanpa TB tanpa memandang status nutrisi mereka. Individu dengan status nutrisi baik tidak selalu identik dengan status mikronutrien yang normal sehingga gangguan imunitas akibat defisiensi mikronutrien tetap dapat terjadi.

Dalam penelitian di India oleh Ray $\mathrm{dkk}^{12}$ mendapatkan kadar seng plasma pasien TB anak akan meningkat dengan sendirinya setelah mendapatkan terapi OAT dan mencapai nilai normal setelah 6 bulan menjalani terapi OAT. Kadar seng plasma pasien TB pada penelitian kami menunjukkan nilai yang terendah $(8,5 \pm 1,8) \mu \mathrm{mol} / \mathrm{L}$ sebelum dimulainya terapi OAT dan meningkat menjadi $(9,6 \pm 1,2) \mu \mathrm{mol} / \mathrm{L}$ pada periode kurang 2 bulan dan $(9,1 \pm 2,1) \mu \mathrm{mol} / \mathrm{L}$ setelah $>2$ bulan mendapatkan terapi. Terlihat bahwa rerata kadar seng plasma subjek yang mendapat terapi lebih 2 bulan lebih rendah daripada subjek yang mendapat terapi kurang 2 bulan, disebabkan karena dua bulan pertama terapi TB merupakan fase eradikasi kuman TB dan merupakan periode perbaikan klinis pasien TB secara nyata. Kadar seng plasma sedikit menurun dan meningkat secara perlahan-lahan sampai akhir terapi.

Subjek dengan uji Mantoux negatif mempunyai kadar seng plasma yang lebih rendah dibandingkan dengan subjek dengan uji Mantoux positif (7,2 $\pm 3,5 \mu \mathrm{mol} / \mathrm{L}$ dan $8,8 \pm 1,5 \mu \mathrm{mol} / \mathrm{L})$. Hasil yang serupa juga ditunjukkan dalam beberapa penelitian sebelumnya. ${ }^{12,14,18}$ Temuan tersebut sejalan dengan peran seng dalam sistem imun selular, hipozincemia menyebabkan penurunan proliferasi dan aktivitas limfosit $\mathrm{T}$ dalam respons imun terhadap kuman TB termasuk respons terhadap uji tuberkulin. Hasil negatif palsu terhadap uji tuberkulin menyebabkan diagnosis TB anak menjadi lebih sulit dan dapat menyebabkan keterlambatan diagnosis dan terapi pasien TB anak.

\section{Kesimpulan}

Hipozinsemia didapatkan pada 25 dari 30 pasien TB anak dengan rerata kadar seng plasma pasien TB anak $(9,0 \pm 1,8)$ 
$\mu \mathrm{mol} / \mathrm{L}$, merupakan kadar seng plasma di bawah nilai normal. Kadar seng plasma paling rendah ada pada kelompok pasien TB anak yang belum mendapat terapi OAT dan lebih tinggi pada pasien yang telah mendapat terapi OAT. Ternyata pasien dengan uji Mantoux negatif mempunyai rerata kadar seng plasma lebih rendah daripada pasien dengan uji Mantoux positif.

\section{Daftar Pustaka}

1. Dye C, Scheele S, Dolin P, Pathania V, Raviglione MC. Global burden of tuberculosis. Estimated incidence, prevalence, and mortality by country. JAMA 1999;282:677-86.

2. Communicable Diseases World Health Organization. Global tuberculosis control: WHO report 2007. Diunduh dari: http://www.who.int/tb/publications/ global_report/2007/pdflmethods.pdf. Diakses tanggal: 13 November 2007.

3. Rahajoe NN, Basir D, Makmuri MS, Kartasasmita CB, penyunting. Pedoman nasional tuberkulosis anak. Edisi ke-2. Jakarta: UKK Respirologi PP Ikatan Dokter Anak Indonesia; 2007.h.4-34.

4. Schluger NW, Rom WN. The host immune response to tuberculosis. Am J Respir Crit Care 1998;157:679-91.

5. Shankar AH, Prasad AS. Zinc and immune function: the biological basis of altered resistance to infection. Am J Clin Nutr 1998;68:447S-63.

6. Karyadi E, Schultink W, Nelwan RHH, Gross R, Amin Z, Dolmans WMV, dkk. Poor micronutrient status of active pulmonary tuberculosis patients in Indonesia. Am Soc Nutr Sci 2000:2953-8.

7. Boras Z, Juretic A, Rudolf M, Uzarevic B, Trescec A. Cellular and humoral immunity to purified protein derivative (PPD) in PPD skin reactive and nonreactive patients with pulmonary tuberculosis: comparative analysis of antigenic-specific lymphocyte proliferation and IgG antibodies. Croat Med J 2002;43:301-5.

8. Shankar AH, Prasad AS. Zinc and immune function: the biological basis of altered resistance to infection. Am J Clin Nutr 1998;68(suppl):447S-63S.

9. WHO. Zinc, Environmental health criteria 221, World Health Organization; 2001.h.100-22.

10. Iyengar V, Woittiez J. Trace elements in human clinical specimens: Evaluation of literature data to identify reference values. Clin Chem 1988;34:474-81.

11. King JC. Assessment of zinc status. J Nutr 1990; 120:1474-9.

12. Ray M, Kumar L, Prasad R. Plasma zinc status in Indian childhood tuberculosis: impact of antituberculosis therapy. Int J Tuberc Lung Dis 1998;2:719-25.

13. McMurray DN, Bartow RA, Mintzer CL, HernandezFrontera E. Micronutrient status and immune function in tuberculosis. Ann NY Acad Sci 1990;587:59-69.

14. Karyadi E, Schultink W, Nelwan RHH, Gross R, Amin Z, Dolmans WMV, dkk. A double blind placebocontrolled study of vitamin A and zinc supplementation in patients with pulmonary tuberculosis in Indonesia: the effect on clinical response and nutritional status. J Nutr 2000;130:72-94.

15. Departemen Kesehatan Republik Indonesia. Survei prevalensi tuberkulosis tahun 2004. Badan Penelitian dan Pengembangan Kesehatan, Departemen Kesehatan Republik Indonesia. 2004.

16. Supriyatno B, Rahajoe NN, Rahajoe N, Boediman I, Said M, Setyanto DB. Karakteristik tuberkulosis anak dengan biakan positif. Cermin Dunia Kedok 2002:22-5.

17. Cegielski JP, McMurray DN. The relationship between malnutrition and tuberculosis: evidence from studies in human and experimental animals. Int J Tuberc Lung Dis 2004;8:286-98.

18. Kramer TR, Udomkesmalee E, Dhanamitta S, Sirisinha S, Charoenkiatkul S, Tuntipopipat S, dkk. Lymphocyte responsiveness of children supplemented with vitamin A and zinc. Am J Clin Nutr 1993;58:566-70. 